\title{
HUBUNGAN INTERAKSI SOSIAL DENGAN TINGKAT DEPRESI PADA LANSIA DI PANTI SOSIAL TRESNA WERDHA BUDI SEJAHTERA PROVINSI KALIMANTAN SELATAN
}

\section{Correlation Between Social Interaction With The Level of Depression in Elderly at The Panti Sosial Tresna Werdha Budi Sejahtera, South Kalimantan Province}

\author{
Theresia jamini $^{1 *}$ \\ Fandi Jumaedy ${ }^{2}$ \\ Dwi Martha Agustina ${ }^{3}$
}

*ISTIKES Suaka Insan, Banjarmasin, Kalimantan Selatan, Indonesia

2STIKES Suaka Insan, Banjarmasin, Kalimantan Selatan, Indonesia

3STIKES Suaka Insan, Banjarmasin, Kalimantan Selatan, Indonesia

*email: star.chr@gmail.com

\section{Kata Kunci:}

Depresi

Interaksi Sosial

Lansia

Keywords:

Depression

Social Interaction

Elderly

\begin{abstract}
Abstrak
Masalah kesehatan sering kali terjadi pada lansia, yang mempengaruhi interaksi sosial. Kondisi tersebut bisa menjadi salah satu pencetus terjadinya depresi pada lansia di panti. Kejadian depresi yang dialami lansia yang tinggal di lokasi penelitian sebanyak $50-75 \%$ disebabkan kesepian, putus asa, hilangnya teman hidup, serta hilangnya peran social Jenis penelitian ini adalah kuantitatif Non-eksperimen, rancangan penelitian korelasional dengan pendekatan cross sectional. Sebanyak 75 responden di Panti Sosial Tresna Werdha Budi Sejahtera Provinsi Banjarbaru, Kalimantan Selatan diambil dengan teknik purposive sampling, dan dalam penelitian ini digunakan kuisioner sebagai instrumen penelitian. Uji statistik menggunakan Korelasi Spearman Rank pada taraf signifikan 0,05 dan hasil penelitian menunjukkan bahwa sebanyak 32 responden interaksi sosial tergolong cukup dan sebanyak 32 responden tingkat depresinya sedang. Hasil uji statistik menggunakan korelasi Spearman Rank didapatkan nilai Correlation Coefficient sebesar 0,580 dan p-value sebesar 0,000 < a 0,05. Dengan demikian dapat dinyatakan bahwa ada hubungan interaksi sosial dengan tingkat depresi pada lansia di panti sosial tersebut.
\end{abstract}

\begin{abstract}
Health problems often occur in the elderly, which affect social interactions. This condition can be one of the triggers for depression in the elderly in the nursing home. The incidence of depression experienced by the elderly who live in the study location is $50-75 \%$ due to loneliness, hopelessness, loss of a spouse, and loss of social roles. This type of research is quantitative non-experimental, correlational research design with cross sectional approach. A total of 75 respondents at the Panti Sosial Tresna Werdha Budi Sejahtera, Banjarbaru, South Kalimantan, were taken by purposive sampling technique, and in this study a questionnaire was used as a research instrument. The statistical test used the Spearman Rank Correlation at a significant level of 0.05 and the results showed that 32 respondents had sufficient social interaction and 32 respondents had moderate depression level. The results of statistical tests using the Spearman Rank correlation obtained the Correlation Coefficient value of 0.580 and a $p$-value of 0.000
\end{abstract}

(C) year The Authors. Published by Institute for Research and Community Services Universitas Muhammadiyah Palangkaraya. This is Open Access article under the CC-BY-SA License (http://creativecommons.org/licenses/by-sa/4.0/). DOI: https://doi.org//0.33084/jsm.vxix.xxx.

\section{PENDAHULUAN}

Menurut World Health Organisation (WHO), lansia adalah seseorang yang telah memasuki usia 60 tahun keatas. Lansia merupakan kelompok umur pada manusia yang telah memasuki tahapan akhir dari fase kehidupannya. Kelompok yang dikategorikan lansia ini akan terjadi suatu proses yang disebut Aging Process atau proses penuaan. Di Indonesia, batasan mengenai lanjut usia adalah 60 tahun ke atas. Lanjut usia adalah seseorang yang telah mencapai usia 60 tahun ke atas, 
baik pria maupun wanita (Kushariyadi, 20II). Lansia sendiri bukan merupakan suatu penyakit, namun merupakan tahap lanjut dari suatu proses kehidupan yang ditandai dengan penurunan kemampuan tubuh untuk beradaptasi dengan stres lingkungan (Pudjiastuti, 2003 dalam Efendi, 2009). Proses tua tersebut alami terjadi dan ditentukan oleh Tuhan Yang Maha Esa. Setiap orang akan mengalami proses menjadi tua dan masa tua merupakan akan mengalami kemunduran fisik mental, dan sosial secara bertahap (Azizah, 20I I). Secara global pada Tahun 2013, proporsi dari populasi penduduk berusia lebih dari 60 tahun adalah II,7\% dari total populasi dunia dan diperkirakan jumlah tersebut akan terus meningkat seiring dengan peningkatan usia harapan hidup. Data WHO menunjukan pada tahun 2000 usia harapan hidup orang didunia adalah 66 tahun, pada tahun 2012 naik menjadi 70 tahun dan pada tahun 2013 menjadi 7I tahun. Jumlah proporsi lansia di Indonesia juga bertambah setiap tahunnya. Data WHO pada tahun 2009 menunjukan lansia berjumlah 7,49\% dari total populasi, tahun 201 I menjadi 7,69\% dan pada Tahun 2013 didapatkan proporsi lansia sebesar 8,1\% dari total populasi (WHO, 20I5). Sementara itu, World Health Organization memperkirakan bahwa tingkat prevalensi keseluruhan gangguan depresi di kalangan lansia pada umumnya bervariasi antara 10\% dan $20 \%$. Pada penelitian hampir lima juta dari 31 juta orang Amerika Serikat berusia 65 tahun atau lebih memiliki gejala depresi mencapai 13\% pada lansia berusia 80 tahun. Depresi pada populasi lansia Amerika Serikat adalah 8,1\% mengalami depresi berat, depresi ringan adalah 14,1\%, sementara lebih $24 \%$ pasien menderita depresi karena penyakit tertentu seperti fungsi organ menurun, stroke, dan gangguan penglihatan. Prevalensi terjadinya depresi pada lansia di negara tertentu yaitu $29.0 \%$ di negara Indonesia $33.8 \%$, Vietnam adalah $17.2 \%$, dan Jepang adalah $30.3 \%$ dan yang paling tinggi salah satunya termasuk negara Indonesia dibandingkan dengan negara lain. Berkaitan dengan interaksi sosial pada lansia, Simmons (1945), mengemukakan bahwa kemampuan lansia untuk terus menjalin interaksi sosial merupakan kunci untuk mempertahankan status sosialnya atas dasar kemampuannya untuk melakukan tukar-menukar (Maryam, 2008). Berkurangnya interaksi sosial usia lanjut dapat menyebabkan perasaan terisolir, perasaan tidak berguna sehingga usia lanjut menyendiri atau mengalami isolasi sosial dan menyatakan bahwa seseorang yang menginjak lanjut usia akan semakin meningkat perasaan isolasinya dan kondisi ini rentan terhadap depresi (Sehanto, 2013). Menurut the national old people's walfare council di Inggris (Philipson, 2013) menyatakan depresi merupakan salah satu gangguan psikologis dalam urutan atas yang diderita oleh lanjut usia. Banyaknya stressor yang muncul pada lanjut usia serta menurunnya kemampuan beradaptasi dapat menjadi penyebab depresi. Depresi pada lanjut usia juga berpotensi kearah perilaku bunuh diri jika disertai dengan gejala rasa cemas, rasa putus asa yang besar, rasa tidak berharga, gangguan tidur berat, dan gangguan pola makan. Gangguan depresi pada lanjut usia tersebut akan memperburuk kualitas hidup dan meningkatkan risiko bunuh diri. Dampak dari menurunnya kesehatan mental dan gangguan psikososial pada lansia, akan menyebabkan bergesernya peran lansia dalam interaksi sosial di masyarakat maupun dalam keluarga. Selain itu sikap lansia yang cenderung egois dan enggan mendengarkan pendapat orang lain, mengakibatkan lansia merasa terasing secara sosial yang pada akhirnya merasa terisolir dan tidak berguna, karena tidak ada penyaluran emosional melalui bersosialisasi. Keadaan ini menyebabkan interaksi sosial menurun baik secara kualitas maupun kuantitas, karena peran lansia digantikan oleh generasi muda, dimana keadaan ini terjadi sepanjang hidup dan tidak dapat dihindari. Hal ini juga akan mengakibatkan depresi sehingga kemandirian lansia dalam memenuhi kebutuhan sehari-hari akan terganggu Kaplan, Sadock dan Grebb, 2007). Berdasarkan studi pendahuluan pada tanggal 07 oktober 2019, di Panti Sosial Tresna Werdha Budi Sejahtera Banjarbaru, Provinsi Kalimantan Selatan dengan 
Theresia Jamini, Fandi Jumaedy, Dwi Martha Agustina. 2020. Correlation Between Social Interaction With The Level of Depression in Elderly at The Panti Sosial Tresna Werdha Budi Sejahtera, South Kalimantan Province

observasi peneliti melihat ada sebagian dari mereka kurang berinteraksi dengan lansia lainnya, seperti komunikasi dan kurang berbaur, sebagai contoh nyata sebagian lansia saat berkumpul bersama lansia yang lain hanya diam saja tidak ada pembicaraan sama sekali, ada juga yang mau berkomunikasi tapi jarang. beberapa lansia nampak murung, menyendiri, dan kurangnya bergaul. Sementara hasil wawancara pada studi pendahuluan pada 10 oktober 2019 di panti sosial yang sama, menunjukan bahwa 10 lansia yang dilakukan wawancara, ada 7 orang lansia ini mengatakan bosan, tidak sering berinteraksi, lebih senang hidup sendiri dan tidak mau berkumpul dengan teman-temannya. Hal ini menunjukan bahwa lansia mengalami perubahan tingkah laku atau perilaku yang berdampak tidak baik bagi individu lansia tersebut. Adapun yang 3 orang lainnya menjawab dengan antusias dan mereka mengatakan tidak bosan berada ditempat ini, senang bertemu dengan orang banyak dan aktif berinteraksi dengan temantemannya. Berdasarkan latar belakang diatas makadilakukan kajian "Hubungan antara interaksi sosial dengan tingkat depresi pada lansia di Panti Sosial Tresna Werdha Budi Sejahtera Banjarbaru Provinsi Kalimantan Selatan".

\section{METODOLOGI}

\section{Jenis Penelitian}

Jenis penelitian ini merupakan kuantitatif yang menggunakan rancangan penelitian Non-Eksperimen, dengan jenis rancangan penelitian korelasional dengan pendekatan cross-sectional.

\section{Populasi}

Populasi dalam penelitian ini adalah seluruh lansia di Panti Sosial Tresna Werdha Budi Sejahtera Banjarbaru Provinsi Kalimantan Selatan, sebanyak II6 orang, yang terdiri dari 54 orang laki-laki, dan 62 orang perempuan.

\section{Sampel}

Dalam penelitian ini yang menjadi sampel adalah lansia yang di Panti Sosial Tresna Werdha Budi Sejahtera Banjarbaru, Provinsi Kalimantan Selatan yang berjumlah 75 orang lansia yang menjadi sampel. Dengan teknik nonprobability sampling dengan jenis purposive sampling. Pengambilan dengan sesuai dengan kriteria inklusi dan kriteria eksklusi.

\section{Alat Pengumpulan Data}

Pengumpulan data menggunakan kuesioner.

\section{Teknik Analisa Data}

Analisis univariat dibuat dalam bentuk tabel distribusi frekuensi dan narasi berdasarkan masing-masing kategori variabel. Analisis bivariat menggunakan Spearman Rank.

\section{HASIL DAN PEMBAHASAN}

\section{Karakteristik Responden}

a. Berdasarkan Usia Lansia

Karekteristik responden berdasarkan usia disajikan pada Tabel I.

Tabel I. Karakteristik Responden Berdasarkan Usia Lansia

\begin{tabular}{|l|c|c|}
\hline Usia (Tahun) & F & $\%$ \\
\hline 60-74 Tahun (Ederly) & 75 & 100 \\
\hline Jumlah & 75 & 100 \\
\hline
\end{tabular}

Berdasarkan Tabel I, usia lansia pada penelitian ini berada direntang 60 - 74 tahun, usia ini adalah disebut dengan lanjut usia (elderly), maka dari itu peneliti hanya mengambil sampel dari rentang usia 60 - 74 tahun, karena usia dibawah 60 tahun belum dikatakan lanjut usia, sedangkan diatas 74 tahun disebut dengan lanjut usia tua.

b. Berdasarkan Jenis Kelamin

Karakterisik reponden berdasarkan jenis kelamin disajikan pada Tabel 2.

Tabel 2. Karakteristik Responden Berdasarkan Jenis Kelamin

\begin{tabular}{|l|c|c|}
\hline \multicolumn{1}{|c|}{ Jenis Kelamin } & F & \% \\
\hline Laki-Laki & 34 & 45.3 \\
\hline Perempuan & $4 I$ & 54.7 \\
\hline Jumlah & 75 & 100 \\
\hline
\end{tabular}

Dari Tabel 2 tampak bahwa, dilihat dari jenis kelamin jumlah responden perempuan lebih banyak dibandingkan jumlah responden laki-laki yaitu sebanyak 
4 I lansia (54.7\%). Berdasarkan data di panti dalam keseluruhan lansia jenis kelamin perempuan lebih banyak dari pada laki-laki, begitu juga dengan sampel yang didapat lebih banyak perempuan dari pada laki-laki karena peneliti mengambil sampel sesuai dengan kriteria inklusi dan kriteria eklusi.

\section{Analisa Univariat}

a. Interaksi Sosial Pada Lansia

Data interaksi sosial pada lokasi penelitian disajikan pada Tabel 3.

Tabel 3. Interaksi Sosial Pada Lansia

\begin{tabular}{|c|l|c|c|}
\hline No & \multicolumn{1}{|c|}{ Interaksi Sosial } & F & $\%$ \\
\hline I & Baik & 23 & 30.7 \\
\hline 2 & Cukup & 32 & 42.7 \\
\hline 3 & Kurang & 20 & 26.7 \\
\hline Jumlah & 75 & 100 \\
\hline
\end{tabular}

Berdasarkan Tabel 3, diketahui bahwa dari 75 lansia ditemukan paling banyak interaksi sosial dengan kategori cukup, yakni sebanyak 32 lansia (42.7\%). Interaksi sosial merupakan suatu proses di mana manusia melakukan komunikasi dan saling mempengaruhi dalam tindakan maupun pemikiran. Penurunan derajat kesehatan dan kemampuan fisik menyebabkan lansia secara perlahan akan menghindar dari hubungan dengan orang lain. Hal ini akan mengakibatkan interaksi sosial menurun (Hardywinoto, T. S, 2005).

b. Tingkat Depresi Pada Lansia

Data tingkat depresi pada lansia di lokasi penelitian disajikan pada Tabel 4.

Tabel 4. Tingkat Depresi Pada Lansia

\begin{tabular}{|c|l|c|c|}
\hline No & \multicolumn{1}{|c|}{ Tingkat Depresi } & F & $\%$ \\
\hline I & Ringan & 21 & 28 \\
\hline 2 & Sedang & 32 & 42.7 \\
\hline 3 & Berat & 22 & 29.3 \\
\hline Jumlah & 75 & 100 \\
\hline
\end{tabular}

Berdasarkan Tabel 4, diketahui bahwa dari 75 lansia ditemukan paling banyak tingkat depresi dengan kategori sedang, yakni sebanyak 32 lansia (42.7\%). Menurut (Townsend, 2009) dikemukakan bahwa depresi merupakan salah satu gangguan alam perasaan (mood) yaitu adanya penurunan mood dengan ditandai adanya perasaan sedih, putus asa, kehilangan minat dalam beraktivitas, munculnya gejala pada gangguan fisik, nafsu makan berubah serta pola tidur juga berubah.

\section{Analisa Bivariat}

Analisis data Hubungan Interaksi Sosial dengan Tingkat Depresi pada Lansia disajikan pada Tabel 5.

Tabel 5. Hubungan Interaksi Sosial dengan Tingkat Depresi pada Lansia

\begin{tabular}{|l|l|l|}
\hline \multicolumn{2}{|l}{} & Tingkat Depresi \\
\hline Interaksi Sosial & $\mathrm{R}$ & 0.580 \\
& $\mathrm{P}$ & 0.000 \\
& $\mathrm{~N}$ & 75 \\
\hline
\end{tabular}

Dari Tabel 5, tampak bahwa hasil uji statistik dengan uji korelasi Spearman Rank hubungan antara interaksi sosial dengan tingkat depresi pada lansia diperoleh hasil nilai $P=0,000<\alpha 0,05$ artinya, menyatakan adanya hubungan antara interaksi sosial dengan tingkat depresi pada lansia dengan nilai Correlations Coeffecient $r$ 0.580 berada pada rentang 0.400 sampai dengan 0.599 ini membuktikan bahwa terdapat hubungan yang sedang antara interaksi sosial dengan tingkat depresi pada lansia di Panti Sosial Tresna Werdha Budi Sejahtera Banjarbaru Provinsi Kalimantan Selatan Tahun 2020. Berdasarkan hasil penelitian di panti pada lansia yang interaksi sosialnya dalam kategori kurang akan tetapi tingkat depresinya berat karena lansia tersebut tidak terlalu aktif dalam berinteraksi jika ditanya saja lansia tersebut dapat berkomunikasi, akan tetapi lansia tersebut kebanyakan berdiam diri, dan menyendiri. $\mathrm{Hal}$ itu dikarenakan lansia kurangnya penyesuaian diri yang baik dengan lansia lainnya. Lansia yang memiliki interaksi sosial yang kurang, salah satunya disebabkan oleh usia. Menurut Fitria (20II), umumnya lansia mengalami penurunan dalam melakukan interaksi. Semakin bertambah usia menyebabkan penurunan interaksi sosial sehingga lansia akan merasakan kesulitan dalam bersosialisasi. Berdasarkan hasil penelitian dipanti pada lansia yang interaksi sosialnya dalam kategori baik akan tetapi tingkat depresinya berat karena lansia tersebut 
Theresia Jamini, Fandi Jumaedy, Dwi Martha Agustina. 2020. Correlation Between Social Interaction With The Level of Depression in Elderly at The Panti Sosial Tresna Werdha Budi Sejahtera, South Kalimantan Province

dalam sisi fisik ada terganggu seperti sulit berjalan, tidak dapat mendengar, penglihatan kurang jelas, dan tidak dapat melakukan aktivitas, sehingga lansia tersebut sulit untuk bersosialisasi dikarenakan adanya perubahan fisik pada individu tersebut. Tetapi, lansia tersebut mampu berkomunikasi atau berinteraksi sosial dengan baik. Berdasarkan hasil analisa korelasi ( $r$ ) didapat korelasi antara interaksi sosial dengan tingkat depresi pada lansia (r) adalah 0.580. hal ini menunjukan bahwa terjadi hubungan yang sedang antara interaksi sosial dengan tingkat depresi pada lansia. Sedangkan arah hubungan adalah positif karena nilai $r$ positif, berarti semakin tinggi interaksi sosialnya maka semakin rendah tingkat depresinya. Penelitian yang dilakukan Andreany Kusumowardani dan Aniek Puspitosari (2014) di desa Sobokerto Kecamatan Ngemplak Boyolali menunjukan bahwa adanya hubungan signifikan dengan tingkat korelasi sedang antara tingkat depresi lansia dengan interaksi sosial, semakin rendah tingkat depresinya maka semakin tinggi tingkat interaksi sosialnya begitu pula sebaliknya. Penurunan kondisi fisik dan psikologis menjadi penyebab utama gangguan interaksi sosial seseorang. Kondisi ini berakibat pada penurunan interaksi sosial lansia. Dengan demikian perubahan fisik dan psikologis seseorang mempengaruhi interaksi sosial mereka, seperti yang dikemukakan oleh Hurlock (1990) bahwa lanjut usia ditandai dengan perubahan fisik dan psikologis tertentu. Dikemukakan pula oleh Hurlock, efek tersebut menentukan lansia dalam melakukan penyesuaian diri secara baik atau buruk, akan tetapi ciriciri lanjut usia cenderung menuju dan membawa penyesuaian diri yang buruk dari pada yang baik dan kepada kesengsaraan dari pada kebahagiaan, itulah sebabnya mengapa usia lanjut lebih rentan dari pada usia madya. Hasil penelitian yang berbeda dikemukakan oleh Novitasari (2019) di Panti Wreda Budi Luhur Yogyakarta memiliki interaksi sosial yang baik (7I,8\%) yang mengindikasikan bahwa kondisi di panti cukup baik. Hasil distribusi frekuensi tingkat depresi yang diteliti menunjukkan bahwa sebagian besar responden mengalami depresi sedang (42,7\%) dilanjutkan dengan depresi ringan dan depresi berat dan ini menunjukkan bahwa lansia yang tinggal di panti tidak mengalami gejalagejala depresi yang terlalu buruk. Menurut Stuart (2006), depresi adalah suatu kesedihan dan perasaan yang berkepanjangan atau abnormal. Saroson (1999) mengemukakan bahwa wanita lebih mempunyai resiko 2 kali lebih besar dibanding laki-laki untuk menderita depresi. Darmojo (1999) lansia yang dapat menghadapi perubahan dengan tetap bisa menjalin komunikasi dengan orang lain akan mudah menghadapi perubahan dengan lebih positif dan dapat mengisi masa tuanya dengan optimal. Selain itu lansia yang tinggal di panti memiliki interaksi sosial yang baik dan sebagian besar di antaranya tidak mengalami depresi. Ini berarti bahwa interaksi sosial yang terjalin baik diantara penghuni panti mampu menekan tingkat depresi yang dialami oleh lansia.

\section{KESIMPULAN}

Secara statistik uji korelasi Spearman Rank ada hubungan interaksi sosial dengan tingkat depresi pada lansia yang tinggal di Panti Sosial Tresna WerdhaBudi Sejahtera Banjarbaru Provinsi Kalimantan Selatan, dengan nilai $p=0,000<0,05$.

Hubungan interaksi sosial dengan tingkat depresi pada lansia didapatkan nilai Correlations Coeffecient r 0.580 berada pada rentang 0.400 sampai dengan 0.599 ini membuktikan bahwa terdapat hubungan yang sedang antara interaksi sosial dengan tingkat depresi pada lansia di Panti Sosial Tresna Werdha Budi Sejahtera Banjarbaru, Provinsi Kalimantan Selatan.

\section{REFERENSI}

I. Azizah, L. M. 20II. Keperawatan Lanjut Usia Edisi I. Yogyakarta: Graha Ilmu.

2. World Health Organization, 2015. Global Status Report on Noncommunicable Disease. Diakses: 8 Oktober 2019. 
http://apps.who.int/iris/bitstream/ / 0665/79059/I/ WHO_DCO_WHD_2013.2_eng.pdf.

3. Maryam, S et al. 2008. Mengenal Lanjut Usia \& Perawatannya, Jakarta: Salemba Medika.

4. Sehanto. 2013. Tentang Hubungan Interaksi Sosial dengan Tingkat Depresi pada Lanjut Usia di Desa Leyangan Kecamatan Ungaran Timur Kabupaten Semarang.

5. Kaplan, Saddock dan Grebb. 2007. Physiogical Testing. Jakarta : Rineka Cipta.

6. Hardywinoto, T. S. 2005. Panduan Gerontologi : Tinjauan Dari Berbagai Aspek. Jakarta : PT. Gramedia Pustaka Utama.

7. Townsend, MC. (2009). Psychiatric Mental Health Nursing Concepts of Care in Evidence-Based Practice. (6th ed) Philadelphia: Davis Plus Company.

8. Fitria, A. 20II. Interaksi Sosial dengan Kualitas Hidup Lansia di Panti Werdha UPT Pelayanan Sosial Lanjut Usia dan Anak Balita Wilayah Binjai dan Medan : USU Medan.

9. Kusumowardani, Andreany dan Aniek Puspitosari. 20I4. "Hubungan antara Tingkat Depresi Lansia dengan Interaksi Sosial Lansia di Desa Sobokerto Kecamatan Ngemplak Boyolali” (diakses 2 Oktober 2019)

10. Hurlock, Elizabeth. 1990. Psikologi Perkembangan. edisi kelima, Erlangga Jakarta

II. Novitasari. 2019. Hubungan Interaksi Sosial Dengan Tingkat Depresi Pada Lanjut Usia Di Panti Sosial Tresna Werdha Unit Budi Luhur Yogyakarta. Sekolah Tinggi Ilmu Kesehatan 'Aisyiyah Yogyakarta

12. Saroson. 1999. Sosial-Environmental fackloes in unipolar Depression Comorison of pttient and non Depressed Control. Journal of abnormal Psychology vol. 92.no2.USA.

13. Darmojo, Boedhi dan Hadi Martono. 2006. Buku Ajar Geriatri (IImu Kesehatan Usia Lanjut). Jakarta : Balai Penerbit FK UI
14. Stuart, G.W. 2006. Buku Saku Keperawatan Jiwa Edisi 5.EGC.Jakarta. 